\title{
URAN, THORIUM A DRASLÍK V KRYSTALINIKU A PALEOZOICKÝCH SEDIMENTECH NA MAPOVÉM LISTU 14-33 POLIČKA - LABORATORNÍ GAMASPEKTROMETRIE A PARCIÁLNÍ CHEMICKÉ SLOŽENÍ VARISKÝCH PLUTONITU゚
}

\author{
Uranium, thorium and potassium in crystalline rocks and Palaeozoic sediments in the \\ map sheet 14-33 Polička - a laboratory gamma-ray spectrometry and particular chemical \\ composition of Variscan plutonites
}

\author{
Jiří Zimák \\ Katedra geologie PřF UP, tř. 17. listopadu 12, 771 46 Olomouc; e-mail:jiri.zimak@upol.cz
}

(14-33 Polička)

Key words: Polička Crystalline Complex, Svratka Crystalline Complex, Hlinsko Unit, gamma-spectrometry

\begin{abstract}
The paper deals with natural radioactivity of metamorphic and igneous rocks and Palaeozoic sediments within the map sheet 14-33 Polička. Studied rocks belong to three geological units: the Hlinsko Zone (phyllites and quartzites of the Mrákotín Fm., flysch sediments of the Hlinsko-Rychmburk Fm.), the Svratka Crystalline Complex (mainly mica schists, paragneisses, orthogneisses and migmatites, also amphibolites, skarns, erlans and quartzites) and the Polička Crystalline Complex (mica schists, paragneisses to migmatites and the Variscan granitoids are dominant). Concentrations of potassium, uranium and thorium were measured using a laboratory gamma-ray spectrometer in 805 rock samples. Data are tabled and discussed. Natural radioactivity of rocks is evaluated on the basis of the calculated values of mass activity of ${ }^{226} \mathrm{Ra}$ equivalent $\left(a_{m}\right)$. Slightly increased $a_{m}$ values were found in migmatites and orthogneisses of the Svratka Crystalline Complex (187 Bq. $\mathrm{kg}^{-1}$ on average), granites and granodiorites of the Budislav Pluton (216 Bq. $\mathrm{kg}^{-1}$ ), granodiorites and rocks of a tonalite suite of the Miretín Pluton (199 and $194 \mathrm{~Bq} \cdot \mathrm{kg}^{-1}$ ). Increased concentrations of uranium and thorium were found in some samples of pegmatite and aplite. Radioactivity of rocks of the Hlinsko-Rychmburk and Mrákotín Fms. can be assessed as relatively low.
\end{abstract}

Úvod

Významným parametrem prrírodního prostředí je jeho přirozená radioaktivita. Proto je součástí vysvětlivek k souborům geologických a ekologických účelových map přírodních zdrojů ČR v měřítku 1:50 000 hodnocení radioaktivity hornin, založené převážně na datech získaných leteckou aeroradiometrií a gamaspektrometrií. $\mathrm{Na}$ základě letecké geofyziky lze posoudit přirozenou radioaktivitu jednotlivých geologických jednotek a případně odhadnout kategorii radonového rizika, avšak $\mathrm{z}$ více důvodů není možno zhodnotit radioaktivitu jednotlivých horninových typů. Ve vysvětlivkách k listu 14-33 Polička (Šalanský - Manová 2000) je proto radioaktivita krystalinika komentována jen velmi stručně. Citovaní autoři však upozorňují na zvýšené obsahy všech tří gamaspektrometricky sledovaných prvků (K, U a Th) v metamorfitech svrateckého krystalinika u Svratky a také v pásmu granodioritu až dioritu mezi Herálcem, Krounou a dále na JZ (jde o miřetínský pluton), s poznámkou, že „obdobné horniny, zřejmě více dioritového charakteru, tvořící v. okraj poličského krystalinika, se jeví jako podprůměrně radioaktivní“ (v tomto případě jde o budislavský pluton). Hrubou představu o prrirozené radioaktivitě horninových komplexů v zájmové oblasti poskytují publikace Manová - Matolín (1989, 1995).

V tomto článku jsou sumarizovány údaje o obsazích hlavních přirozených radioaktivních prvků (K, U a Th) $\mathrm{v}$ metamorfitech, magmatitech a paleozoických sedimentech na mapovém listu 14-33 Polička na základě laboratorních gamaspektrometrických analýz velkého souboru vzorků. V něm jsou zastoupeny jak dominantní horninové typy ze všech níže zmíněných geologických jednotek a jejich částí, tak i typy, které jsou zde př́tomny jen zcela lokálně. Připojeny jsou poznámky k chemismu variských plutonitů, založené na výsledcích XRF analýz provedených $\mathrm{v}$ laboratorních podmínkách.

\section{Geologické jednotky a jejich horninová náplň}

Nemetamorfované až slabě regionálně metamorfované paleozoikum (lokálně postižené kontaktní metamorfózou) a krystalinikum na listu 14-33 Polička náleží ke třem geologickým jednotkám: hlinské zóně, poličskému krystaliniku a svrateckému krystaliniku (autor zde respektuje terminologii užitou v legendě mapového listu a ve vysvětlivkách $\mathrm{k}$ němu - Stárková et al. 1998, 2000).

Hlinská zóna je na listu 14-33 Polička reprezentována mrákotínským a hlinsko-rychmburským souvrstvím. Mrákotínské souvrství je zde tvořeno fylity a také kvarcity (oba horninové typy jsou často silně grafitické). Ve flyšoidním hlinsko-rychmburském souvrství se střídají fylitické břidlice a psamity (převažují droby), přítomny jsou vložky konglomerátů (dominují gravelity) - např. Maštera (2004).

Převažujícím horninovým typem poličského krystalinika na listu 14-33 Polička jsou drobnozrnné až jemnozrnné biotitické nebo dvojslídné pararuly s relativně vysokým podílem křemene, přecházející do kvarcitických parurul až kvarcitů. Značně rozšířeny jsou perlové a migmatitické ruly (biotitické až muskovit-biotitické) 
a také svory (dvojslídné, často granátické), plošně málo významné jsou amfibolity a mramory. Stručnou charakteristiku metamorfitů poličského krystalinika uvádí Stárková et al. (2000), detailně se jimi zabývá Buriánek (2009a, b - druhá z prací je však založena na studiu vzorků odebraných mimo list 14-33 Polička).

Při severním okraji poličského krystalinika na listu 14-33 Polička vystupují na dvou územích variské plutonity (viz Stárková et al. 1998). Na větším $z$ nich (cca $3 \times 15 \mathrm{~km})$, které probíhá od Zderaze (ssz. od Proseče) k Borové a Kamenci u Poličky, jde hlavně o biotitický až muskovit-biotitický granit až granodiorit (tyto horniny tvoří zderazský masiv - Buriánek 2009a), biotitický až amfibol-biotitický tonalit až granodiorit nebo křemenný diorit (společně s granity v budislavském plutonu - podrobnou petrografickou charakteristiku uvádí Buriánek 2009a). Druhé území s variskými intruzivy je vymapováno jako pruh (cca $1 \times 7 \mathrm{~km})$, oddělující poličské a svratecké krystalinikum od hlinské zóny (Stárková et al. 1998, 2000). V novější literatuře (např. Buriánek 2009a; Vondrovic et al. 2011) je zde vystupující intruzívní těleso označováno jako miřetínský pluton. Mapující geologové v něm rozlišili dva typy granitoidů: a) biotitický granodiorit, v legendě mapy (Stárková et al. 1998) označovaný jako „kataklazovaný muskoviticko-biotitický až biotitický granit (typ Hlinsko,
Miřetín)“, b) porfyrický biotitický a amfibol-biotitický granodiorit až tonalit (horniny tonalitové suity charakterizuje Buriánek 2009a). V obou zmíněných plutonech jsou drobná tělesa gaber (přecházejících do dioritů), a to zpravidla uvnitř tonalitů (a hornin jim blízkých) nebo v okolních pararulách. Variské plutonity i metamorfity poličského krystalinika bývají prostoupeny pegmatitovými a aplitovými žilami, hojnými zejména v tonalitech (hlavně budislavského masivu) a rulách, ale zjištěnými autorem tohoto článku i v hlinsko-rychmburském souvrství.

Převládajícími horninovými typy svrateckého krystalinika na listu 14-33 Polička jsou dvojslídné ortoruly, migmatity a také dvojslídné svory, výrazně menší rozšíření mají biotitické pararuly, amfibolity, kvarcity, mramory, erlany a skarny (Stárková et al. 1998).

\section{Vzorky a metody}

Na listu 14-33 Polička bylo na 317 lokalitách odebráno 805 vzorků reprezentujících všechny horninové typy ve výše zmíněných geologických jednotkách. Determinace hornin byla prováděna jen makroskopicky, což působilo komplikace u granitoidů, dioritoidů a také gabroidů v prostoru poličského krystalinika. Při přriřazování vzorků $\mathrm{k}$ jednotlivým typům plutonitů se autor

Tab. 1: Obsahy přirozených radioaktivních prvků (K, U, Th) v horninách svrateckého a poličského krystalinika, mrákotínského a hlinsko-rychmburského souvrství, vypočtené hodnoty hmotnostní aktivity ekvivalentu ${ }^{226} \mathrm{Ra}\left(\mathrm{a}_{\mathrm{m}}\right) ; \mathrm{n}=$ počet vzorků, $\mathrm{x}=$ průměr. Tab. 1: Contents of the natural radioactive elements (K, U, Th) in rocks of the Svratka and Polička Crystalline Complexes, Mrákotín and Hlinsko-Rychmburk Formations, calculated mass activity of ${ }^{226}$ Ra equivalent $\left(a_{m}\right) ; n=$ number of samples, $x=$ average.

\begin{tabular}{|c|c|c|c|c|c|c|c|c|c|c|c|c|c|c|c|c|c|}
\hline \multirow{2}{*}{ geol. jednotka / hornina } & \multirow{2}{*}{$\mathrm{n}$} & \multicolumn{4}{|c|}{ K (hm. \%) } & \multicolumn{4}{|c|}{$\mathrm{eU}(\mathrm{ppm})$} & \multicolumn{4}{|c|}{ eTh (ppm) } & \multicolumn{4}{|c|}{$\mathrm{a}_{\mathrm{m}}\left(\mathrm{Bq} \cdot \mathrm{kg}^{-1}\right)$} \\
\hline & & $\min$. & $\max$. & med. & $\mathrm{x}$ & $\min$. & $\max$. & med. & $\mathrm{x}$ & $\min$. & $\max$. & med. & $\mathrm{x}$ & $\min$. & $\max$. & med. & $\mathrm{x}$ \\
\hline \multicolumn{18}{|l|}{ svratecké krystalinikum } \\
\hline svor, svorová rula & 61 & 1,4 & 7,0 & 2,7 & 2,8 & 1,8 & 6,3 & 3,2 & 3,2 & 2,7 & 26,2 & 10,5 & 10,6 & 101 & 383 & 164 & 167 \\
\hline pararula (33) & 15 & 1,4 & 4,1 & 3,0 & 2,9 & $<1,5$ & 5,6 & 3,5 & 3,5 & 5,1 & 20,7 & 10,8 & 11,1 & 116 & 250 & 171 & 178 \\
\hline perlová rula (34) & 10 & 2,8 & 4,5 & 3,6 & 3,7 & 1,6 & 3,0 & 2,5 & 2,4 & 6,7 & 12,3 & 10,1 & 9,7 & 129 & 208 & 177 & 175 \\
\hline migmatit-ortorula (35) & 80 & 1,5 & 5,0 & 3,6 & 3,5 & $<1,5$ & 13,8 & 3,1 & 3,6 & 2,9 & 30,5 & 9,2 & 10,2 & 108 & 356 & 184 & 187 \\
\hline okatá ortorula (36) & 14 & 2,6 & 5,3 & 3,7 & 3,7 & 1,6 & 3,5 & 2,4 & 2,6 & 5,8 & 10,7 & 8,9 & 8,7 & 125 & 219 & 169 & 172 \\
\hline amfibolit & 11 & $<0,5$ & 1,6 & $<0,5$ & $<0,5$ & $<1,5$ & 5,6 & 1,7 & 2,0 & $<1,5$ & 11,0 & 4,0 & 4,6 & 26 & 130 & 66 & 63 \\
\hline skarn & 12 & $<0,5$ & 1,4 & $<0,5$ & $<0,5$ & $<1,5$ & 5,2 & $<1,5$ & 2,0 & $<1,5$ & 13,2 & 6,2 & 6,0 & 26 & 156 & 65 & 72 \\
\hline erlan & 25 & $<0,5$ & 2,7 & $<0,5$ & 0,7 & $<1,5$ & 6,3 & 2,8 & 3,0 & 4,8 & 11,9 & 8,1 & 8,1 & 51 & 148 & 100 & 100 \\
\hline kvarcit & 10 & $<0,5$ & 2,5 & 1,6 & 1,6 & $<1,5$ & 2,0 & $<1,5$ & $<1,5$ & 5,9 & 11,5 & 8,9 & 8,4 & 77 & 137 & 92 & 101 \\
\hline světlý metavulkanit & 5 & 3,7 & 5,3 & 4,6 & 4,5 & 1,7 & 5,1 & 2,9 & 3,4 & 10,4 & 15,7 & 11,2 & 12,3 & 178 & 262 & 217 & 221 \\
\hline \multicolumn{18}{|l|}{ poličské krystalinikum } \\
\hline svor & 24 & 1,0 & 6,6 & 2,2 & 2,5 & 2,1 & 16,1 & 3,2 & 4,0 & 7,3 & 31,1 & 9,2 & 10,6 & 108 & 420 & 147 & 171 \\
\hline pararula $(25+26)$ & 70 & 0,6 & 4,7 & 2,4 & 2,5 & $<1,5$ & 9,1 & 3,1 & 3,6 & 2,1 & 22,7 & 9,7 & 10,1 & 54 & 305 & 159 & 163 \\
\hline migmatitická rula (28) & 52 & 0,6 & 4,9 & 2,5 & 2,7 & $<1,5$ & 10,5 & 2,5 & 3,1 & 3,1 & 38,6 & 9,6 & 11,2 & 64 & 412 & 162 & 168 \\
\hline amfibolit & 12 & $<0,5$ & $<0,5$ & $<0,5$ & $<0,5$ & $<1,5$ & 2,6 & $<1,5$ & $<1,5$ & $<1,5$ & 5,2 & $<1,5$ & $<1,5$ & 26 & 70 & 26 & 30 \\
\hline erlan & 2 & $<0,5$ & $<0,5$ & $<0,5$ & $<0,5$ & 2,6 & 3,5 & 3,1 & 3,1 & 1,7 & 1,9 & 1,8 & 1,8 & 50 & 62 & 56 & 56 \\
\hline mramor & 6 & $<0,5$ & 1,1 & 0,7 & 0,7 & $<1,5$ & 2,5 & 2,0 & 1,9 & $<1,5$ & 7,2 & 5,5 & 4,6 & 26 & 97 & 74 & 67 \\
\hline kvarcit & 3 & $<0,5$ & 1,4 & $<0,5$ & 0,7 & 2,7 & 8,9 & 3,1 & 4,9 & 2,4 & 14,5 & 12,8 & 9,9 & 55 & 202 & 146 & 135 \\
\hline křemen-živcová skalina & 2 & 4,1 & 4,2 & 4,2 & 4,2 & $<1,5$ & 1,6 & $<1,5$ & $<1,5$ & 2,5 & 2,9 & 2,7 & 2,7 & 128 & 135 & 132 & 132 \\
\hline \multicolumn{18}{|l|}{ mrákotínské souvrství } \\
\hline grafitický fylit & 7 & $<0,5$ & $<0,5$ & $<0,5$ & $<0,5$ & 1,5 & 9,3 & 2,4 & 3,4 & $<1,5$ & 3,1 & 1,7 & 1,7 & 35 & 141 & 48 & 60 \\
\hline grafitický kvarcit & 4 & $<0,5$ & $<0,5$ & $<0,5$ & $<0,5$ & 2,6 & 7,9 & 4,9 & 5,1 & $<1,5$ & 2,1 & 1,7 & 1,6 & 46 & 116 & 79 & 80 \\
\hline kvarcit & 2 & $<0,5$ & $<0,5$ & $<0,5$ & $<0,5$ & $<1,5$ & $<1,5$ & $<1,5$ & $<1,5$ & $<1,5$ & 1,6 & $<1,5$ & $<1,5$ & 26 & 30 & 28 & 28 \\
\hline \multicolumn{18}{|c|}{ hlinsko-rychmburské souvrství } \\
\hline slepenec & 6 & $<0,5$ & 1,2 & 0,9 & 0,9 & 2,1 & 13,6 & 4,8 & 5,7 & 6,7 & 8,6 & 7,8 & 7,7 & 77 & 247 & 121 & 136 \\
\hline psamity & 57 & $<0,5$ & 3,0 & 1,2 & 1,3 & $<1,5$ & 8,1 & 2,3 & 2,5 & 4,3 & 12,2 & 7,0 & 7,3 & 52 & 163 & 100 & 103 \\
\hline aleurity a pelity & 24 & 1,7 & 4,0 & 2,7 & 2,8 & $<1,5$ & 7,0 & 2,6 & 2,7 & 4,8 & 10,6 & 8,3 & 8,2 & 94 & 206 & 155 & 148 \\
\hline
\end{tabular}


často opíral o jejich makroskopickou charakteristiku publikovanou Buriánkem (2009a).

V horninových vzorcích byly na PřF UP v Olomouci za použití spektrometru SG - $1000 \mathrm{LAB}$ s NaI(Tl) detektorem o objemu $0,35 \mathrm{dm}^{3}$ (průměr $76 \mathrm{~mm}$, délka $76 \mathrm{~mm}$ ) stanoveny obsahy $\mathrm{K}$ (přímo na základě koncentrace ${ }^{40} \mathrm{~K}$ ), U a Th (na základě dceřiných produktů, a proto jsou jejich obsahy při uvádění výsledků analýz označovány jako eU a eTh). Meze detekce: $\mathrm{K}=0,5 \mathrm{hm}$. \%, U a Th = 1,5 ppm. Při výpočtu hodnot $\mathrm{a}_{\mathrm{m}}$ a $\mathrm{D}$ (viz níže) a při statistickém zpracování dat byly obsahy K pod mezí detekce nahrazeny hodnotou $0,33 \mathrm{hm}$. $\%$, obdobně v prípadě U a Th hodnotou 1 ppm. Před měřením byly horninové vzorky rozdrceny a uzavřeny do krabiček o objemu $250 \mathrm{ml}$, v nichž byly následně měřeny. Hmotnost takto připravených vzorků se pohybovala kolem 400 gramů.

Přirozená radioaktivita hornin je hodnocena na základě hmotnostní aktivity ekvivalentu ${ }^{226} \mathrm{Ra}\left(\mathrm{a}_{\mathrm{m}}\right)$ a též dávkového př́ikonu záření gama terestrického původu (D). Tyto parametry byly $\mathrm{z}$ výsledků gamaspektromet- rických analýz vypočteny pomocí vztahů $\mathrm{a}_{\mathrm{m}}\left[\mathrm{Bq} \cdot \mathrm{kg}^{-1}\right]=$ $(0,077 \times 313 \mathrm{~K})+12,35 \mathrm{U}+(1,43 \times 4,06 \mathrm{Th}), \mathrm{D}\left[\mathrm{nGy} \cdot \mathrm{h}^{-1}\right]$ $=(0,043 \times 313 \mathrm{~K})+(0,427 \times 12,35 \mathrm{U})+(0,662 \times 4,06 \mathrm{Th})$, do nichž je obsah K dosazován v hm. \%, obsahy U a Th v ppm (Beretka - Matthew 1985; UNSCEAR 1988; Matolín - Chlupáčová 1997; Ngachin et al. 2007; Eštoková - Palaščáková 2013).

Údaje o chemismu variských plutonitů byly získány v laboratorních podmínkách pomocí XRF analyzátoru DELTA-PREMIUM v laboratořích firmy URGA, s.r.o. se sídlem v Olomouci (použitou metodiku popisuje Zimák et al. 2016, celkem analyzováno 106 vzorků).

\section{Výsledky}

Výsledky všech provedených laboratorních gamaspektrometrických měření jsou shrnuty v tabulkách 1 a 2. Údaje o chemismu hornin studovaných těles variských plutonitů sumarizuje tabulka 3. Významné či zajímavé poznatky jsou komentovány v následující kapitole.

Tab. 2: Obsahy přirozených radioaktivních prvků (K, U, Th) v intruzivních horninách, vypočtené hodnoty hmotnostní aktivity ekvivalentu ${ }^{226} \mathrm{Ra}\left(\mathrm{a}_{\mathrm{m}}\right) ; \mathrm{n}=$ počet vzorků, $\mathrm{x}=$ průměr.

Tab. 2: Contents of the natural radioactive elements (K, $\mathrm{U}, \mathrm{Th})$ in intrusive rocks, calculated mass activity of ${ }^{226} \mathrm{Ra}$ equivalent $\left(\mathrm{a}_{\mathrm{m}}\right) ; \mathrm{n}=$ number of samples, $\mathrm{x}=$ average.

\begin{tabular}{|c|c|c|c|c|c|c|c|c|c|c|c|c|c|c|c|c|c|}
\hline \multirow{2}{*}{ geol. jednotka / hornina } & \multirow{2}{*}{$\mathrm{n}$} & \multicolumn{4}{|c|}{ K (hm. \%) } & \multicolumn{4}{|c|}{$\mathrm{eU}(\mathrm{ppm})$} & \multicolumn{4}{|c|}{ eTh (ppm) } & \multicolumn{4}{|c|}{$\mathrm{a}_{\mathrm{m}}\left(\mathrm{Bq} \cdot \mathrm{kg}^{-1}\right)$} \\
\hline & & $\min$. & $\max$. & med. & $\mathrm{x}$ & $\min$. & $\max$. & med. & $\mathrm{x}$ & $\min$. & $\max$. & med. & $\mathrm{x}$ & $\min$. & $\max$. & med. & $\mathrm{x}$ \\
\hline \multicolumn{18}{|l|}{ budislavský pluton } \\
\hline granit, granodiorit & 57 & 2,0 & 4,8 & 3,1 & 3,2 & $<1,5$ & 20,3 & 3,7 & 5,1 & 1,9 & 72,5 & 12,6 & 13,4 & 82 & 672 & 195 & 216 \\
\hline tonalit, křemen. diorit & 67 & 1,2 & 3,1 & 1,7 & 1,8 & $<1,5$ & 7,8 & 2,0 & 2,2 & $<1,5$ & 24,4 & 6,4 & 6,9 & 57 & 258 & 102 & 110 \\
\hline gabro, gabro/diorit & 8 & $<0,5$ & 3,6 & 2,0 & 2,0 & $<1,5$ & 4,1 & 2,4 & 2,5 & $<1,5$ & 16,8 & 8,7 & 8,1 & 26 & 208 & 133 & 127 \\
\hline \multicolumn{18}{|l|}{ miřetínskýpluton } \\
\hline granodiorit & 29 & 1,8 & 4,4 & 3,1 & 3,2 & 1,5 & 12,6 & 3,0 & 4,1 & 5,7 & 33,9 & 10,3 & 12,2 & 110 & 406 & 171 & 199 \\
\hline deformovaný granodiorit & 18 & 0,6 & 3,9 & 2,6 & 2,3 & $<1,5$ & 7,7 & 2,2 & 3,1 & 4,6 & 24,1 & 7,0 & 9,6 & 81 & 265 & 120 & 149 \\
\hline alterovaný granodiorit & 6 & $<0,5$ & 1,2 & $<0,5$ & 0,5 & $<1,5$ & 3,6 & 1,7 & 2,0 & 2,4 & 6,3 & 3,6 & 3,8 & 41 & 103 & 49 & 58 \\
\hline tonalit, granodiorit & 26 & 1,3 & 4,4 & 2,6 & 2,8 & $<1,5$ & 10,1 & 3,5 & 3,8 & 6,1 & 23,3 & 12,9 & 13,5 & 112 & 314 & 193 & 194 \\
\hline gabro, gabro/diorit & 8 & $<0,5$ & 1,4 & $<0,5$ & 0,5 & $<1,5$ & 1,5 & $<1,5$ & $<1,5$ & $<1,5$ & 5,8 & $<1,5$ & 2,4 & 26 & 71 & 26 & 39 \\
\hline \multicolumn{18}{|l|}{ zderazský masiv } \\
\hline granit, granodiorit & 34 & 1,5 & 3,0 & 2,5 & 2,4 & $<1,5$ & 26,5 & 2,4 & 4,4 & 5,3 & 16,4 & 10,6 & 10,9 & 112 & 439 & 161 & 177 \\
\hline \multicolumn{18}{|c|}{ pegmatity (včetně pegmatoidních granitů) a aplity } \\
\hline pegmatit & 26 & 1,0 & 6,8 & 3,6 & 4,0 & $<1,5$ & 25,1 & 2,8 & 5,3 & $<1,5$ & 24,6 & 3,9 & 6,9 & 59 & 526 & 158 & 202 \\
\hline aplit & 12 & 3,0 & 5,0 & 3,6 & 3,7 & 2,2 & 18,2 & 3,8 & 5,5 & 7,2 & 45,3 & 12,4 & 15,1 & 164 & 608 & 202 & 244 \\
\hline
\end{tabular}

Tab. 3: Obsahy vybraných prvků v plutonitech (XRF analýzy, celkové železo uvedeno jako $\mathrm{Fe}_{2} \mathrm{O}_{3}, \mathrm{n}=$ počet vzorků).

Tab. 3: The contents of selected elements in plutonic rocks (XRF analysis, total iron is presented as $\mathrm{Fe}_{2} \mathrm{O}_{3}, \mathrm{n}=$ number of samples).

\begin{tabular}{|c|c|c|c|c|c|c|c|c|c|c|c|c|c|c|c|c|}
\hline \multirow{2}{*}{ geol. jednotka / hornina } & \multirow{2}{*}{$\mathrm{n}$} & \multicolumn{3}{|c|}{$\mathrm{SiO}_{2}(\mathrm{hm} . \%)$} & \multicolumn{3}{|c|}{$\mathrm{Al}_{2} \mathrm{O}_{3}(\mathrm{hm} . \%)$} & \multicolumn{3}{|c|}{$\mathrm{Fe}_{2} \mathrm{O}_{3}(\mathrm{hm} . \%)$} & \multicolumn{3}{|c|}{$\mathrm{CaO}(\mathrm{hm} . \%)$} & \multicolumn{3}{|c|}{$\mathrm{K}_{2} \mathrm{O}(\mathrm{hm} . \%)$} \\
\hline & & $\min$. & $\max$ & med. & $\min$. & $\max$. & med. & $\min$. & $\max$. & med. & $\min$. & $\max$. & med. & $\min$. & $\max$. & med. \\
\hline \multicolumn{17}{|l|}{ budislavský pluton } \\
\hline granit, granodiorit & 24 & 66,0 & 82,6 & 70,4 & 12,0 & 15,9 & 13,2 & 0,8 & 2,5 & 1,4 & $<0,7$ & 2,2 & 1,4 & 2,9 & 5,8 & 4,6 \\
\hline tonalit, křemen. diorit & 21 & 52,1 & 66,1 & 58,7 & 9,7 & 15,0 & 13,5 & 4,4 & 7,2 & 5,6 & 2,9 & 6,2 & 4,8 & 1,1 & 2,8 & 2,1 \\
\hline gabro, gabro/diorit & 5 & 42,8 & 51,6 & 43,9 & 8,7 & 15,8 & 12,1 & 6,9 & 10,8 & 7,8 & 3,8 & 13,0 & 9,1 & 0,5 & 4,0 & 1,2 \\
\hline \multicolumn{17}{|l|}{ miřetínský pluton } \\
\hline granodiorit & 19 & 64,6 & 76,2 & 71,7 & 11,1 & 14,9 & 13,0 & 0,6 & 2,4 & 1,4 & $<0,7$ & 2,3 & $<0,7$ & 3,1 & 5,9 & 4,6 \\
\hline deformovaný granodiorit & 8 & 65,6 & 80,1 & 73,0 & 10,9 & 14,0 & 11,8 & 0,7 & 2,7 & 1,4 & $<0,7$ & 3,1 & 1,1 & 1,7 & 6,0 & 3,8 \\
\hline alterovaný granodiorit & 3 & 72,4 & 88,1 & 87,1 & 3,4 & 10,4 & 4,4 & 1,0 & 2,6 & 1,7 & $<0,7$ & 1,0 & $<0,7$ & $<0,2$ & 1,3 & 0,2 \\
\hline tonalit, granodiorit & 8 & 52,6 & 69,2 & 65,6 & 12,0 & 14,3 & 13,1 & 2,6 & 6,1 & 4,2 & 1,5 & 6,5 & 2,8 & 2,5 & 5,8 & 3,8 \\
\hline gabro, gabro/diorit & 4 & 39,8 & 51,3 & 40,7 & 12,5 & 14,2 & 13,1 & 7,8 & 11,8 & 10,1 & 7,3 & 12,6 & 11,6 & 0,3 & 1,7 & 0,3 \\
\hline \multicolumn{17}{|l|}{ zderazský masiv } \\
\hline granit, granodiorit & 14 & 65,3 & 74,0 & 68,8 & 12,4 & 14,9 & 13,3 & 0,7 & 2,5 & 1,8 & 1,6 & 2,1 & 1,8 & 2,1 & 4,4 & 3,3 \\
\hline
\end{tabular}




\section{Diskuze}

1. Převedení gamaspektrometricky stanovených obsahů $\mathrm{K}, \mathrm{U}$ a Th na hodnotu $\mathrm{a}_{\mathrm{m}}$ umožňuje jednoduše vyjádřit prrirozenou radioaktivitu horniny a obdobně lze využít i hodnotu D. Kdy však lze považovat konkrétní hodnotu $\mathrm{a}_{\mathrm{m}}$ (nebo $\mathrm{D}$ ) za relativně vysokou nebo naopak nízkou? Jako nejlogičtější se nabízí srovnání $\mathrm{s}$ hodnotami $\mathrm{a}_{\mathrm{m}}$ (nebo $\mathrm{D}$ ) vypočtenými výše uvedeným způsobem $\mathrm{z}$ klarků $\mathrm{K}, \mathrm{U}$ a Th, tedy $\mathrm{z}$ jejich průměrných obsahů $\mathrm{v}$ zemské kůře. $\mathrm{V}$ literatuře uváděné klarky pro konkrétní chemický prvek se často výrazně liší jak v závislosti na kvantitě a kvalitě dat, tak i na způsobu jejich zpracování. Z klarkových hodnot zveřejněných Goldschmidtem v roce 1937 (viz např. Bouška et al. 1980), kdy jde o 2,59 hm. \% K, 4 ppm U a 11,5 ppm Th, je vypočtená $\mathrm{a}_{\mathrm{m}} 179 \mathrm{~Bq} \cdot \mathrm{kg}^{-1}\left(\mathrm{D}=87 \mathrm{nGy} \cdot \mathrm{h}^{-1}\right)$. Rudnick - Gao (2005) pro svrchní část zemské kůry kontinentálního typu uvádí $2,80 \mathrm{hm}$. \% $\mathrm{K}_{2} \mathrm{O}(=2,32 \mathrm{hm}$. \% K), 2,7 ppm U a 10,5 ppm Th. Tomu odpovídá $\mathrm{a}_{\mathrm{m}} 150 \mathrm{~Bq} \cdot \mathrm{kg}^{-1}(\mathrm{D}=74$

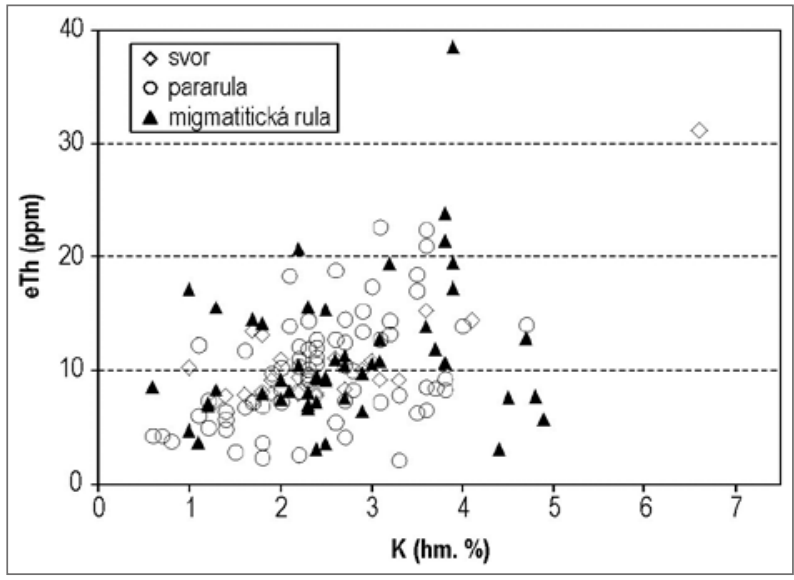

Obr. 1: Korelace draslík versus thorium ve svorech, pararulách a migmatitických rulách poličského krystalinika.

Fig. 1: The correlation of potassium versus thorium in mica schists, paragneisses and migmatitic gneisses of the Polička Crystalline Complex.

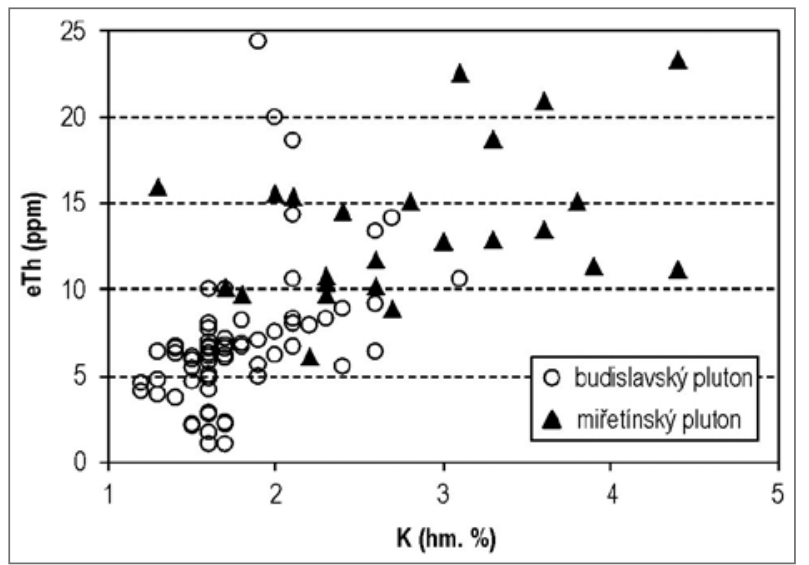

Obr. 2: Korelace draslík versus thorium v amfibol-biotitických granodioritech až tonalitech budislavského a miřetínského plutonu.

Fig. 2: The correlation of potassium versus thorium in amphibole-biotite granodiorite to tonalite of the Budislav and Miřetín Plutons.
nGy.h ${ }^{-1}$ ). Z klarků vypočtených jinými autory (přehled poskytuje např. Rudnick - Gao 2005) lze samozřejmě odvodit jiné hodnoty $\mathrm{a}_{\mathrm{m}}$ a $\mathrm{D}$. Pro posouzení míry radioaktivity hornin na listu 14-33 Polička byla zvolena hodnota $\mathrm{a}_{\mathrm{m}}$ kalkulovaná $\mathrm{z}$ klarků Goldschmidta (po zaokrouhlení $\left.180 \mathrm{~Bq} \cdot \mathrm{kg}^{-1}\right)$. Nutno doplnit, že průměrná hodnota globálního D je odhadována na 55 nGy.h-1 (UNSCEAR 1988; Manová - Matolín 1995), střední hodnota D pro území ČR je 65,6 \pm 19,0 nGy.h ${ }^{-1}$ (Manová - Matolín 1995).

Průměrná $\mathrm{a}_{\mathrm{m}}$ dominantních horninových typů krystalinika na listu 14-33 Polička (tab. 1 a 2) přibližně odpovídá hodnotě vypočtené pro průměrnou zemskou kůru (cca 180 Bq. $\mathrm{kg}^{-1}$ ). Z kvantitativně významných horninových typů mají průměrné hodnoty $a_{m}$ nad $180 \mathrm{~Bq} \cdot \mathrm{kg}^{-1}$ jen migmatity a ortoruly svrateckého krystalinika (viz bod 2 diskuze), granity a granodiority budislavského a miřetínského plutonu a také horniny tonalitové suity druhého $\mathrm{z}$ intruzivních těles (bod 5).

2. V poli přirozené radioaktivity je plošně významnou pozitivní anomálií území při jižním okraji mapového listu mezi Pustou Rybnou, Svratouchem a Svratkou. V tomto území vystupují migmatity a ortoruly svrateckého krystalinika, včetně typických okatých ortorul (v tabulce 1 jsou v souladu s koncepcí mapového listu uvedeny jako dvě samostatné položky označené čísly 35 a 36). Jejich průměrná $\mathrm{a}_{\mathrm{m}}$ je 187 a $172 \mathrm{~Bq} \cdot \mathrm{kg}^{-1}(\mathrm{D}=93$ a 87 nGy.h $\left.{ }^{-1}\right)$. V některých vzorcích těchto hornin byly zjištěny zvýšené obsahy uranu: až 13,8 ppm eU v migmatitizované ortorule z PP Zkamenělý zámek (k. ú. Česká Cikánka). Jen nepatrně nižší přirozenou radioaktivitu vykazují metapelity svrateckého krystalinika.

3. Ve svrateckém krystaliniku mají nejvyšší průměrnou $\mathrm{a}_{\mathrm{m}}\left(221 \mathrm{~Bq} \cdot \mathrm{kg}^{-1}\right)$ leukokratní drobnozrnné křemen-živcové horniny, $\mathrm{v}$ tabulce 1 označené pracovně na základě jejich vzhledu jako „světlé metavulkanity“. Tyto horniny byly zjištěny na k. ú. Pustá Kamenice a Rychnov jako ojedinělé úlomky v eluviu (př́íp. deluviu) vždy společně s fragmenty muskovitických kvarcitů (někdy jde o živcové kvarcity). Muskovitické kvarcity jsou vyjádřeny v geologické mapě (Stárková et al. 1998, položka legendy č. 41), o přítomnosti hornin typu „světlých metavulkanitü“ nebo „živcových kvarcitů“ v kvarcitových polohách není zmínka ani ve vysvětlivkách (Stárková et al. 2000).

4. Průměrná $\mathrm{a}_{\mathrm{m}}$ dominantních hornin poličského krystalinika je nepatrně nižší ve srovnání s $a_{m}$ vypočtenou pro průměrnou zemskou kůru. Pro skupinu svorů, pararul a migmatitických rul byly stanoveny průměrné hodnoty $\mathrm{a}_{\mathrm{m}} 171,163$ a $168 \mathrm{~Bq} \cdot \mathrm{kg}^{-1}$ (v uvedeném pořadí), jimž odpovídají hodnoty D 83, 79 a 83 nGy.h ${ }^{-1}$. Buriánek (2009b) na základě chemismu hornin považuje svory poličského krystalinika za metapelity, ruly spíše za metapsamity (metadroby). Svory a ruly poličského krystalinika (včetně migmatitizovaných typů na styku se svrateckým krystalinikem) se svými obsahy K, U a Th nijak zásadně neliší (tab. 1, obr. 1), na povahu protolitu (pelit versus psamit) $\mathrm{z}$ těchto dat usuzovat nelze. Je možné, že v průběhu metamorfózy docházelo k redistribuci uranu. Snížené obsahy tohoto prvku byly zaznamenány v migmatitických 
rulách. Lokálně zvýšené koncentrace uranu byly zjištěny ve svorech (až 16,1 ppm eU ve svoru z k. ú. Otradov).

5. Pozitivní anomálie $\mathrm{v}$ poli přirozené radioaktivity jsou vázány na variské granitoidy (tab. 2). Nejvyšší průměrné hodnoty $\mathrm{a}_{\mathrm{m}}\left(216 \mathrm{~Bq} \cdot \mathrm{kg}^{-1}\right)$ a $\mathrm{D}\left(105 \mathrm{nGy} \cdot \mathrm{h}^{-1}\right)$ byly vypočteny pro granity a granodiority budislavského plutonu, pro něž je charakteristický velmi široký interval obsahů K, U a Th (tab. 2) i dalších složek (tab. 3), vysoká variabilita obsahů $\mathrm{K}$ a Th je zřejmá i $\mathrm{z}$ obrázku 3, v němž však není vyznačen vzorek s anomálně vysokým obsahem thoria (72,5 ppm eTh). Zvýšenou radioaktivitu v rámci této skupiny hornin vykazují žilné granity, často aplitického charakteru (viz bod 6 této kapitoly). Ve srovnání $s$ granity a granodiority je přirozená radioaktivita hornin tonalitové suity budislavského plutonu (amfibol-biotitické granodiority až tonality) přibližně poloviční (průměrná $\left.\mathrm{a}_{\mathrm{m}}=110 \mathrm{~Bq} \cdot \mathrm{kg}^{-1}, \mathrm{D}=54 \mathrm{nGy} \cdot \mathrm{h}^{-1}\right)$.

Odlišné poměry jsou $\mathrm{v}$ miřetínském plutonu, $\mathrm{v}$ němž zvýšenou přirozenou radioaktivitu mají i horniny

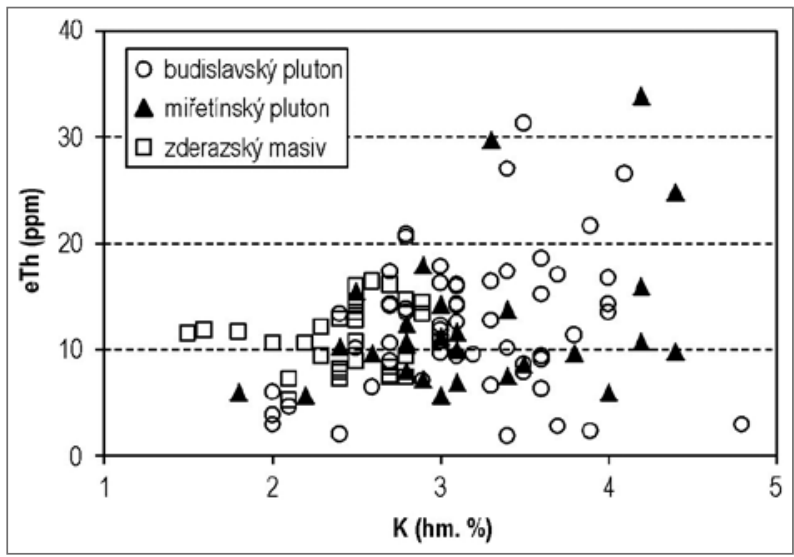

Obr. 3: Korelace draslík versus thorium v granitech až granodioritech budislavského a miřetínského plutonu a zderazského masivu.

Fig. 3: The correlation of potassium versus thorium in granite to granodiorite of the Budislav and Miřetín Plutons and the Zderaz Massif.

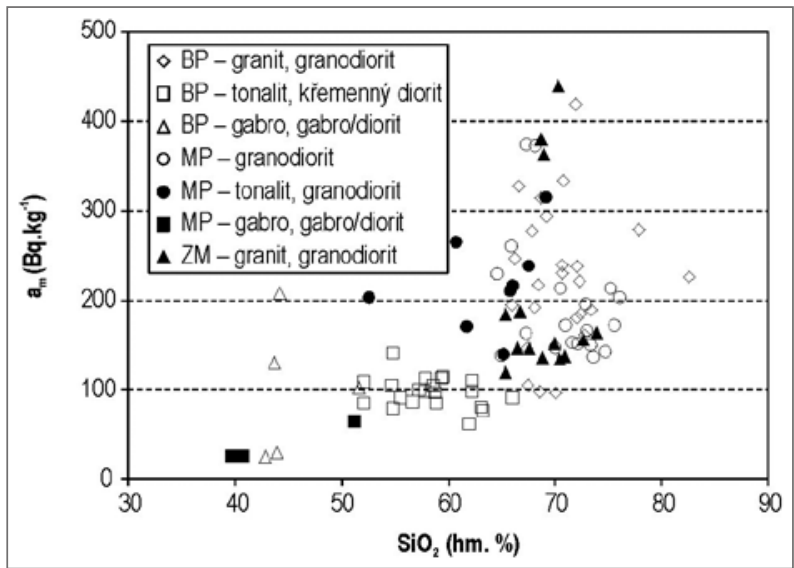

Obr. 4: Korelace $\mathrm{SiO}_{2}$ versus $\mathrm{a}_{\mathrm{m}}$ v horninách budislavského plutonu (BP), miřetínského plutonu (MP) a zderazského masivu (ZM). Fig. 4: The correlation of $\mathrm{SiO}_{2}$ versus $\mathrm{a}_{\mathrm{m}}$ in rocks of the Budislav Pluton (BP), the Miřetín Pluton (MP) and the Zderaz Massif (ZM). tonalitové suity (viz tabulka 2, srovnání hornin tonalitové suity obou plutonů je zř̀jmé z obrázku 2). Biotitický granodiorit miřetínského plutonu je výrazně postižen deformací (submagmatickou až vysokoteplotní deformací v již pevném stavu - viz Vondrovic et al. 2011). Již v terénu lze rozlišit úseky, kde je stupeň deformace granodioritu relativně nízký, od úseků, v nichž vystupují horniny víceméně rulového charakteru. $\mathrm{V}$ jižní části miřetínského plutonu (při rozhraní k. ú. Oldřiš u Hlinska a Krouna) jsou na polích místy hojné úlomky hydrotermálně alterovaných hornin, snad původně také granodioritů. $\mathrm{V}$ tabulce 2 jsou proto vzorky granodioritů miřetínského plutonu rozděleny do tří souborů označených jako „granodiorit“" (jde o horniny s jen slabými projevy deformace), „deformovaný granodiorit“ a „alterovaný granodiorit“. Deformace granodioritu byla provázena poklesem obsahů $\mathrm{K}, \mathrm{U}$ a Th, k výraznému výnosu všech tří prvků došlo během hydrotermální alterace (tab. 2). Ta má charakter intenzívní silicifikace horniny. To je zřejmé již makroskopicky, výsledky XRF analýz dokládají podstatné zvýšení obsahu Si při současném výrazném snížení obsahů $\mathrm{Al}$ a K v alterované hornině (tab. 3). Z hlediska hodnocení hydrotermální alterace těchto hornin by patrně zásadní význam měly údaje o obsazích $\mathrm{Na}$, které jsou však použitými laboratorními metodami nestanovitelné.

V prostoru zderazského masivu vystupují pouze granity a granodiority, které se makroskopicky velmi podobají granitům a granodioritům budislavského plutonu (jak nerostným složením a strukturou, tak i zbarvením - často jde o růžově zbarvené horniny). Obsahem přirozených radioaktivních prvků se však blíží slabě deformovanému biotitickému granodioritu miřetínského plutonu (tab. 2, obr. 3 a 4 - na obou obrázcích jsou biotitické granodiority miřetínského plutonu reprezentovány pouze horninami $s$ jen relativně slabými projevy deformace). Makrochemismem se granity a granodiority všech tří studovaných těles nijak zásadně neliší, alespoň pokud jde o obsahy $\mathrm{Si}, \mathrm{Al}, \mathrm{Fe}, \mathrm{Ca}$ a K (viz tab. 3 a obr. 5). Značná podobnost makrochemismu suit plutonických hornin budislavského a miřetínského plutonu je zřejmá $\mathrm{z}$ Harkerova diagramu na obrázku 5, do něhož však nebyly začleněny výše zmíněné „alterované granodiority“ miřetínského plutonu. Ve zderazském masivu byly zjištěny jen kyselé plutonity. Lze konstatovat, že se od kyselých hornin budislavského a miřetínského plutonu liší výrazně nižšími průměrnými obsahy draslíku (tab. 3 a obr. 5).

V souboru granitů a granodioritů zderazského masivu je třemi vzorky zastoupen žilný granit z lomu na Farském vrchu (k. ú. Proseč u Skutče). Vysokými obsahy uranu v rozpětí 20,6 až 26,5 ppm eU se tyto tři vzorky odlišují od všech ostatních vzorků granitů zderazského masivu s max. 5,7 ppm eU. Žilný granit z Farského vrchu má $\mathrm{a}_{\mathrm{m}} 363$ až $439 \mathrm{~Bq} \cdot \mathrm{kg}^{-1}$ (na obrázku 4 jde o tř̌i plné trojúhelníčky s vysokými hodnotami $\mathrm{a}_{\mathrm{m}} \mathrm{v}$ uvedeném intervalu), $\mathrm{a}_{\mathrm{m}}$ ostatních vzorků granitů zderazského masivu je max. 208 Bq. $\mathrm{kg}^{-1}$.

6. Nejvyšší hodnoty přirozené radioaktivity v rámci celého souboru hornin z listu 14-33 Polička byly stanoveny ve dvou vzorcích žilných hornin, charakteru aplitického 

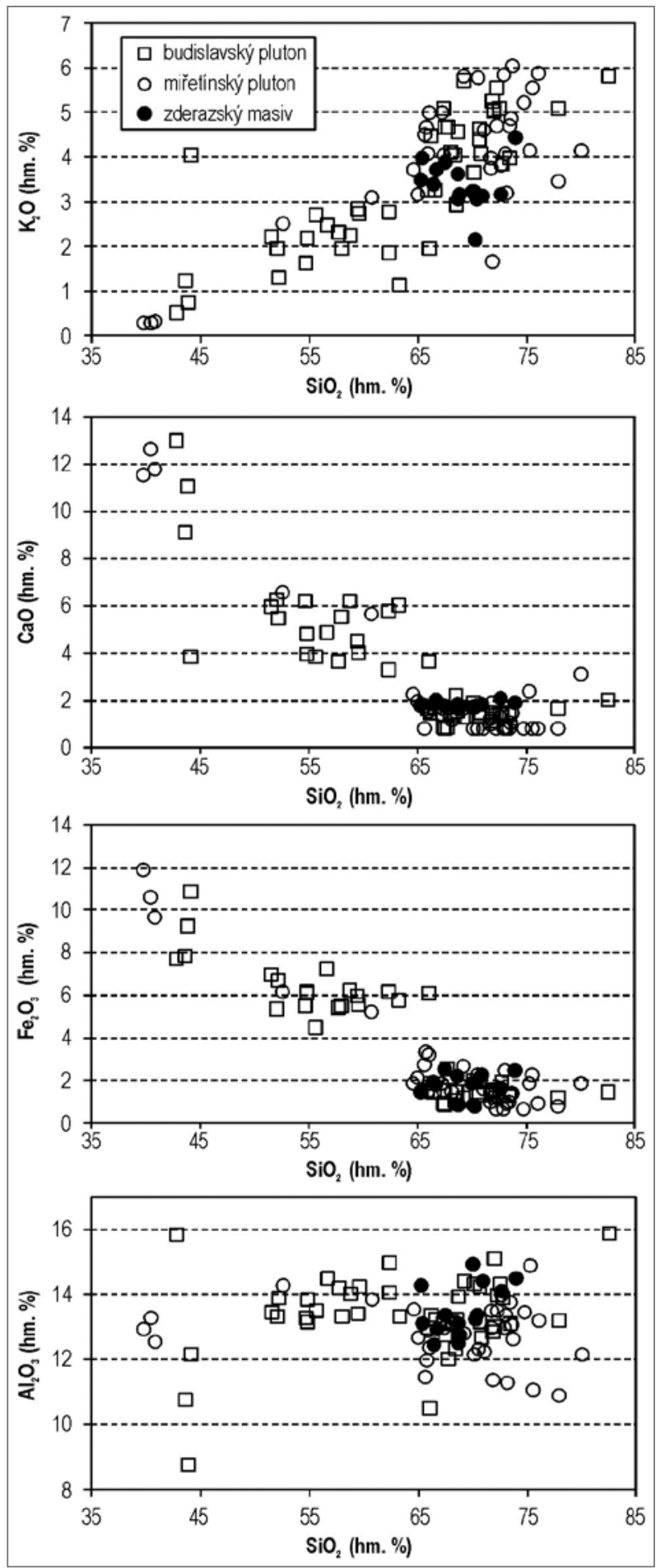

Obr. 5: Harkerův diagram pro plutonické horniny budislavského a miřetínského plutonu a zderazského masivu.

Fig. 5: The Harker diagram for plutonic rocks of the Budislav and Miřetín Plutons and the Zderaz Massif. granitu a aplitu. Vzorek aplitického granitu z k. ú. Lubná u Poličky s 2,1 hm. \% K, 16,2 ppm eU a 72,5 ppm eTh $\left(\mathrm{a}_{\mathrm{m}}=672 \mathrm{~Bq} \cdot \mathrm{kg}^{-1}\right)$ byl odebrán $\mathrm{z}$ bloku v deluviu, cca $250 \mathrm{~m}$ ssz. od kóty 698,8 m (Skalka), s. od Svaté Kateřiny. Lze předpokládat, že pochází z mohutné žíly složené z aplitického a pegmatoidního granitu, probíhající při kontaktu mezi granitoidy budislavského plutonu a perlovými (migmatitickými) rulami poličského krystalinika. $\mathrm{V}$ př́padě druhého vzorku jde o aplit $\mathrm{z} \mathrm{k}$. ú. Miřetín s 5,0 hm. \% K, 18,2 ppm eU a 45,3 ppm eTh $\left(\mathrm{a}_{\mathrm{m}}=608\right.$ Bq. kg $\left.{ }^{-1}\right)$, odebraný z agrární haldy cca $400 \mathrm{~m}$ j. od Miřetína, tj. na území, na němž vystupuje miřetínský pluton.

7. Zvýšené obsahy U a Th byly zaznamenány v některých vzorcích pegmatitů. Jde konkrétně o hrubozrnné křemen-živec-biotitové pegmatity $\mathrm{z} \mathrm{k}$. ú. Budislav u Litomyšle (z činného lomu u Budislavi) s až 25,1 ppm eU a 22,2 ppm eTh $\left(\mathrm{a}_{\mathrm{m}}=526 \mathrm{~Bq} \cdot \mathrm{kg}^{-1}\right)$ a také $\mathrm{z} \mathrm{k}$. ú. Borová u Poličky (opuštěný lom na jz. svahu kóty Štamberk). V př́padě vzorků pegmatitů se zvýšenými koncentracemi U a Th lze konstatovat výraznou pozitivní korelaci mezi oběma prvky.

\section{Závěr}

Průměrná hmotnostní aktivita ekvivalentu ${ }^{226} \mathrm{Ra}$ $\left(\mathrm{a}_{\mathrm{m}}\right)$ dominantních horninových typů svrateckého a poličského krystalinika (svory, pararuly, ortoruly, migmatity a variské granitoidy) na listu 14-33 Polička se nijak zásadně neliší od hodnoty vypočtené $\mathrm{z}$ klarkových obsahů $\mathrm{K}$, U a Th pro průměrnou zemskou kůru (kolem $180 \mathrm{~Bq} \cdot \mathrm{kg}^{-1}$ ). Z kvantitativně významných horninových typů zde mají vyšší průměrnou $a_{m}$ jen migmatity a ortoruly svrateckého krystalinika (187 Bq. $\mathrm{kg}^{-1}$ ), granity a granodiority budislavského plutonu (216 Bq.kg-1), slabě deformované granodiority miřetínského plutonu (199 Bq. $\mathrm{kg}^{-1}$, silně deformované mají $\mathrm{a}_{\mathrm{m}}$ podstatně nižší) a také horniny tonalitové suity miřetínského plutonu (194 Bq. $\left.\mathrm{kg}^{-1}\right)$. Zvýšenou radioaktivitu vykazují pegmatity, aplity, pegmatoidní granity a aplitické granity. Radioaktivitu sedimentů a metasedimentů hlinsko-rychmburského a mrákotínského souvrství lze hodnotit jako relativně nízkou.

\section{Poděkování}

Autor děkuje editorům a recenzentům za kritické pročtení rukopisu a pripomínky, které vedly k jeho zkvalitnění. 


\section{Literatura}

Beretka, J. - Matthew, P. J. (1985): Natural radioactivity of Australian building materials, industrial wastes and by-products. Health Physics, 48, 87-95.

Bouška, V. - Jakeš, P. - Pačes, T. - Pokorný, J. (1980): Geochemie. - Academia, Praha.

Buriánek, D. (2009a): Petrografie poličského krystalinika. - Acta Musei Moraviae, Scientiae geologicae, 94, 3-46.

Buriánek, D. (2009b): Metamorfní vývoj svorů a jejich tektonická pozice v poličském krystaliniku. - Acta Musei Moraviae, Scientiae geologicae, 94, 111-128.

Eštoková, A. - Palaščáková, L. (2013): Study of natural radioactivity of Slovak cements. - Chemical Engineering Transactions, $32,1675-1680$.

Manová, M. - Matolín, M. (1989): Radioaktivita hornin ČSSR. - In: Ibrmajer, J. - Suk, M. et al.: Geofyzikální obraz ČSSR, 196-213. ÚÚG - Academia, Praha.

Manová, M. - Matolín, M. (1995): Radiometrická mapa České republiky 1 : 500 000. Český geologický ústav.

Maštera, L. (2004): Petrofaciální analýza sedimentů „hlineckého paleozoika“. - Geologické výzkumy na Moravě a ve Slezsku $\mathrm{v}$ roce $2003,11,57-58$.

Matolín, M. - Chlupáčová, M. (1997): Radioaktivní vlastnosti hornin. - In: Kobr, M. et al.: Petrofyzika, 109-126. Vydavatelství Karolinum, Praha.

Ngachin, M. - Garavaglia, M. - Giovani, C. - Kwato Njock, M. G. - Nourreddine, A. (2007): Assessment of natural radioactivity and associated radiation hazards in some Cameroonian building materials. - Radiation Measurements, 42, 61-67.

Rudnick, R. L. - Gao, S. (2005): Composition of the continental crust. - In: Rudnick, R. L.: Treatise on geochemistry. Vol. 3 - The crust, 1-64. Elsevier, Amsterdam etc.

Stárková, I. - Adamovič, J. - Müller, V. (2000): Geologie území. - In: Müller, V. (ed.): Vysvětlivky k souboru geologických a ekologických účelových map přírodních zdrojů v měřítku 1:50 000. List 14-33 Polička, 8-22. Český geologický ústav, Praha.

Stárková, I. - Opletal, M. - Adamovič, J. - Macek, J. (1998): Geologická mapa ČR, list 14-33 Polička. Český geologický ústav, Praha.

Šalanský, K. - Manová, M. (2000): Geofyzikální poměry. - In: Müller, V. (ed.): Vysvětlivky k souboru geologických a ekologických účelových map přírodních zdrojů v měřítku 1:50 000. List 14-33 Polička, 23-25. Český geologický ústav, Praha.

UNSCEAR, United Nations Scientific Committee on the Effects of Atomic Radiation (1988): Exposures from natural sources of radiation. Report to the General Assembly. U.N., New York, USA.

Vondrovic, L. - Verner, K. - Buriánek, D. - Halodová, P. - Kachlík, V. - Míková, J. (2011): Emplacement, structural and P-T evolution of the 346 Ma Miřetín Pluton (eastern Teplá-Barrandian Zone, Bohemian Massif): implications for regional transpressional tectonics. - Journal of Geosciences, 56, 4, 343-357.

Zimák, J. - Dalajková, K. - Donocik, R. - Krist, P. - Reif, D. - Štelcl, J. - Kopecká, L. (2016): Využitelnost terénních rentgenfluorescenčních analyzátorů ke stanovení chemismu cementářských surovin - na př́kladu velkolomu Mokrá. - Zprávy o geologických výzkumech, 49, 79-82. 